\title{
POR UMA FICÇÃO AUTOCONSCIENTE: \\ A TRANSPOSIÇÃO DO ROMANCE DOM CASMURRO PARA A MINISSÉRIE CAPITU
}

\author{
Cristiane Passafaro Guzzi \\ Universidade Estadual Paulista \\ São Paulo (SP), Brasil
}

\begin{abstract}
Resumo: $\mathrm{O}$ artigo discute a possibilidade de leitura de duas tradições nos romances, uma realista e outra autoconsciente, as quais se norteiam pelo modo como o gênero romanesco interpretou o conceito de verossimilhança ao longo de sua história. Tal percurso de reflexão possibilitou um estudo da minissérie televisiva Capitu (2008), de Luiz Fernando Carvalho - transposição, essa, da obra Dom Casmurro -, que levou em consideração, também, em seu processo, uma expressa autoconsciência dos mecanismos reflexivos empregados na obra machadiana, mas mobilizados, agora, pelos procedimentos específicos do novo suporte.
\end{abstract}

Palavras-chave: autoconsciência ficcional; transposição sincrética; Luiz Fernando Carvalho.

\section{For a self-conscious fiction: the transposition of the novel Dom Casmurro to the television serial Capitu}

\begin{abstract}
This article discusses the possibility of reading the realistic and the self-conscious traditions of the novel, which are guided by the way the genre interprets the concept of verisimilitude throughout its history. This course of reflection is used here for a study of Luiz Fernando Carvalho's television serial Capitu (2008) - a transposition Dom Casmurro - which has also taken into consideration a manifest self-consciousness of the reflexive mechanisms used in Machado de Assis's novel, but then put into action by the specific procedures of the new medium.
\end{abstract}

Keywords: ficcional self-consciousness; syncretic transposition; Luiz Fernando Carvalho.

Conhecido como um "arqueólogo literário", principalmente por seus trabalhos dedicados aos estudos relacionados às narrativas bíblicas, Robert Alter propôs, em seu 
livro Partial magic: the novel as a self-conscious genre, que se "[...] concebesse a história do romance como uma dialética entre duas tradições: uma autoconsciente e a outra, realista". ${ }^{1}$ Tal reflexão engendra a possibilidade de se entender, ao longo da história, o modo como o gênero romanesco acabou por imbuir a noção de mimese de acordo com os moldes vigentes de determinadas épocas determinados contextos.

O conceito de mimese adquiriu, e vem adquirindo, ao longo dos séculos, diversas interpretações plausíveis (e outras nem tanto), na tentativa de alcançar uma coerente resposta sobre o modo como a representação do real é trabalhada pelos discursos, em especial pelo literário. No caso do gênero romance, se levarmos em consideração a receptividade de algumas das produções realistas que vigoraram em nossa sociedade, podemos perceber a eficácia, por um longo período de tempo, da manifestação recorrente de uma representação que se assemelhe, o tanto quanto possível, da realidade buscada, traduzindo, com precisão e nitidez, os pequenos detalhes de um cotidiano burguês, como bem lembra a estudiosa Tânia Pellegrini. ${ }^{2}$ Corroborando tal afirmação, Alter, em seu artigo "A mimese e o motivo para a ficção", afirma

Nenhuma outra forma na história da literatura ocidental serviu com tanta frequência e tão bem de veículo do leitor para uma experiência vicária. [...] geralmente percebemos um alto grau de mimese efetiva nos romances, ou não estaríamos prontos a aceitar o mundo romanesco equivalente verossímil do nosso próprio mundo. Desde os leitores embaraçosamente ingênuos do tipo ficcionalmente representado em Emma Bovary até os mais refinados intelectuais, temos persistido irresistivelmente, do século XVIII até o atual, a "penetrar" na experiência das personagens de ficção de milhares de romances, trocando vidas com elas, experimentando nossas percepções da realidade contra os detalhes absorventes de seus mundos inventados. ${ }^{3}$

Definido, de modo geral e mais difundido, como um período que se destinou a focar qualquer tipo de representação artística que se dispusesse a reproduzir aspectos

\footnotetext{
${ }^{1}$ ALTER, Robert. Partial magic: the novel as a self-conscious genre. Berkeley, CA: University of California Press, 1975.

2 PELLEGRINI, T. Realismo: postura e método. Letras de hoje. Porto Alegre, v.42, n.4, p.137-155, dez./2007.

3 ALTER, Robert. A mimese e o motivo para a ficção. In: Em espelho crítico. São Paulo: Perspectiva, 1998. p.135.
} 
do mundo referencial, o realismo - seja interpretado como movimento "escolástico", como postura frente ao observável, como método ou efeito de engendramento de uma suposta "ilusão de real" - sempre provocou instigantes perspectivas e consequentes desdobramentos para se pensar sua atuação no contexto literário seja da época vigente, seja da época precedente que o retoma por tradição.

Sabemos que, desde Aristóteles, cada gênero mostra-se com especificidades para a manifestação da mimese. Do mesmo modo que o romance pode ser considerado como o gênero mais apto para se reproduzir o verossímil, podemos também pensar na possibilidade deste reproduzir-se como o locus para a manifestação do inverossímil, ou seja, do fazer ficcional posto em evidência e à mostra. Se considerarmos que a ficção pode ser entendida como verossímil quando há o estabelecimento com o leitor de uma relação de identificação com os códigos mobilizados para a representação, podemos inferir que a presença e/ou a ausência de verossimilhança numa narrativa, por exemplo, pode ser considerada também como um motivo para sua existência.

Nesse sentido, quando Alter aponta para a possibilidade de leitura de duas tradições de concepção da representação no romance, uma realista e outra autoconsciente, há, nesse raciocínio, a velha questão da representação efetiva da mimese nos romances, na qual a tradição realista volta-se para a tentativa de uma reprodução transparente, que se assemelhe ao real das coisas representadas; a tradição autoconsciente, por sua vez, leva-nos para os romances que colocam à mostra o processo ficcional envolto na realização do romance, bem como expõe, de modo reflexivo e sistemático, o romance estar tratando e trabalhando uma ilusão constante. Há um jogo de fingimento necessário, estabelecido entre o autor e seu leitor, para que o conceito de ficcionalidade impere no horizonte de expectativa e confiança dos mesmos.

Um romance autoconsciente é aquele que alardeia sistematicamente a sua condição necessária de artifício e que, ao fazê-lo, investiga a relação problemática entre artifício auto-aparente e realidade. Nos termos de Gombrich, o romancista autoconsciente tem aguda consciência de que está manipulando esquemas, ideando engenhosos criptogramas e inventando constantemente estratégias narrativas para partilhar essa consciência conosco, de tal modo que, simultaneamente, ou alternadamente, cria a ilusão de realidade e a estilhaça. $\mathrm{O}$ romance 
realista, ao contrário, procura manter uma ilusão de realidade relativamente coerente. ${ }^{4}$

A manifesta autoconsciência do fazer ficcional pode nos levar, mais do que propriamente à reprodução "mediada" dos fatos, para uma reflexão pormenorizada sobre os efeitos de sentido, lançados pela enunciação, num determinado enunciado do romance, para que este se materialize como tal. Voltar-se para os procedimentos metalinguísticos trabalhados por uma obra não só retoma a discussão sobre a verossimilhança dos fatos, ao reforçá-los, como pode intensificá-los, ao denunciar sua feitura. Ao privilegiar um ato de escancaramento dos andaimes de construção de um relato, cria-se um efeito ilusório de um real criado e mediado, por intermédio da linguagem, para mostrar-se como tal: artificial. A realidade no romance, então, mostrase em crise ao expor seu processo, mas, ao negar-se, paradoxalmente, consegue afirmarse ainda mais.

O romance autoconsciente vem se tornando uma prática de escritura exercida por muitos escritores contemporâneos que declaram, abertamente e intencionalmente, quererem romper, escancarar e denunciar a exploração do conceito de mimese em seus enredos. Há uma reafirmação da ficcionalidade por intermédio da presença e da exploração do real que se criou com a cultura de massa, meio, esse, que vem se tornando o expoente de matéria para as produções literárias recentes. Contudo, o próprio anúncio de uma tentativa de exaltação da mimese pelas histórias acaba fornecendo matéria diversa de intensificação, problematização e sofisticação do próprio ato de representação que não se queria, aparentemente, ser mais explorado. Anuncia-se não tratar, diretamente, da mimese, tratando dela, narcisicamente, como assunto principal.

Robert Alter enfatiza a existência de uma tradição de autoconsciência desde Miguel de Cervantes "[...] passando por Fielding e Sterne na Inglaterra e Diderot na França, e que veio sofrendo um verdadeiro renascimento no século vinte com escritores como Gide, Queneau, Borges, Nabokov, Pynchon e Fowles". ${ }^{5}$ No contexto brasileiro, um dos romancistas que mais enveredou para os âmbitos dessa tradição autoconsciente foi Machado de Assis. A crise imposta à literatura, desde a segunda metade do século

4 Idem, p.137.

${ }^{5}$ Idem, p.43. 
XIX, afirmou-se em Machado de Assis, quando este retomou a tradição do filósofo Luciano de Samósata, precursor da sátira menipeia, ${ }^{6}$ cujo texto fundador "Diálogo dos mortos", por sua vez, foi escrito pelo filósofo da escola cínica Menipo de Gadara.

Ao remeter-se a essa tradição, Machado passou a superar as limitações estéticas propostas desde o romantismo, ao dar voz a um personagem morto, Brás Cubas, e ao trazer o leitor como um participante ativo de sua construção ficcional. Como aponta Enylton José de Sá Rego, Machado soube reaproveitar as reverberações que a tradição luciânica engendrou, na constituição da sátira menipeia, em seu texto, constituindo-se, esta última, pela mistura de gêneros, pelo uso da paródia, pela extrema liberdade de imaginação, pelo caráter não moralizante e pela exploração de um ponto de vista distanciado. Para José Luiz Fiorin, ${ }^{7}$ Machado veio, portanto, romper com a tradicional conceituação de mimese, postulada desde Aristóteles, ao conceder um livre curso à imaginação e à fantasia; desse modo, "[...] [s]ua sátira não tem um caráter moralizante, uma vez que opera com o gênero sério-cômico, apresentando sempre uma posição ambígua diante dos acontecimentos".

Infere-se, assim, que a crise da tradição mimética, entendida em seu sentido tradicional de representação da realidade e como verossimilhança aristotélica, é posta em jogo por Machado, o qual, ao recusar tais propostas estéticas que eram vigentes no seu tempo, acaba por mostrar, escancaradamente, a ficcionalização existente em seu processo artístico, principalmente em seus romances considerados, pela crítica, como os da "segunda fase" ou "fase madura": Memórias póstumas de Brás Cubas, de 1880, Quincas Borba, de 1891, Dom Casmurro, de 1899, Esaú e Jacó, de 1904 e Memorial de Aires, de 1908. Vale ressaltar que são nos três primeiros romances referidos - os quais compõem uma espécie de trilogia "dialógica" - que verificamos a crise da representação figurada com mais evidência, assim como identificamos, de modo mais explícito, as características que norteiam a tradição dos romances reflexivos, uma vez que há, neles, uma acentuada migração de motivos, temas e, principalmente, de configurações

\footnotetext{
${ }^{6}$ Para um estudo aprofundado sobre a relação existente entre Machado de Assis e a sátira menipeia, indicamos o trabalho inovador de Enylton José de Sá Rego, com seu livro O calundu e a panaceia: Machado de Assis, a sátira menipeia e a tradição luciânica. Rio de Janeiro: Forense Universitária, 1989.

${ }^{7}$ FIORIN, José Luiz. Introdução ao pensamento de Bakhtin. São Paulo: Ática, 2006. p. 112.
} 
discursivas que reiteram a filiação de Machado não só à sátira menipeia, mas à forma shandiana configurada pelo escritor Laurence Sterne.

Para Sergio Paulo Rouanet, ${ }^{8}$ as relações que Machado de Assis e outros escritores, como Almeida Garret, Denis Diderot e Xavier de Maistre, estabeleceram com a obra A vida e as opiniões do cavalheiro Tristram Shandy [The life and opinions of Tristram Shandy, gentleman], de Laurence Sterne, definiram o que pode corresponder às características que a crítica denominou "forma shandiana", a qual, ainda segundo o autor, se define: (1) pela presença constante e caprichosa do narrador; (2) pela digressividade e pela fragmentação (obra difusa, não linear); (3) pelo tratamento especial, fortemente subjetivo, dado ao tempo (os paradoxos da cronologia) e ao espaço (as viagens); e (4) pela interpenetração do riso e da melancolia. A exploração, portanto, de alguns traços da sátira menipeia e da forma shandiana, ${ }^{9}$ revela o modo como Machado veio instaurar diferentes procedimentos discursivos em seus romances, inaugurando e propondo novos meios e caminhos de engendramento estilístico e temático numa época em que o ressoo do romantismo e da consolidação do realismo fazia-se candente.

Em seu texto "Realismo: postura e método", Tânia Pellegrini afirma que

O que se modifica, nas obras ficcionais subsequentes, do Romantismo e do Realismo brasileiro (aqui tomados como "estilo" ou "escola"), são as posturas e os métodos adotados por seus autores, os traços mentais e afetivos que imprimem às suas narrativas, a escolha e a disposição dos detalhes da vida quotidiana observados, em suma, a organização e articulação coerentes dos materiais textualmente representados, consubstanciando, em maior ou menor grau, a interrelação dialética entre indivíduo e sociedade em cada momento, explicitada sobretudo no abandono da idealização e da realidade, tal qual se fazia na Europa. ${ }^{10}$

\footnotetext{
${ }^{8}$ ROUANET, Sergio Paulo. Riso e melancolia: a forma shandiana em Sterne, Diderot, Xavier de Maistre, Almeida Garret e Machado de Assis. São Paulo: Companhia das Letras, 2007. p. 31.

${ }^{9}$ Não tratarei, neste artigo, pormenorizadamente, das reverberações que a influência da sátira menipeia e da forma shandiana engendraram nas obras machadianas, pois tal assunto demandaria um trabalho outro, com enfoque diferente deste artigo. Contudo, indico a leitura das obras mencionadas para um maior aprofundamento de tais relações.

${ }^{10}$ PELLEGRINI, Tânia. Realismo: postura e método. Letras de hoje. Porto Alegre, v.42, n.4, p.137-155, dez./2007, p. 150.
} 
O Realismo brasileiro, em especial, mostrou um método e uma postura diferentes principalmente pelo modo como Machado de Assis soube romper, trabalhar, ultrapassar e, principalmente, combinar a "representação de um intervalo social menor" - como define Alfredo Bosi ${ }^{11}$ a respeito da representação social em Machado - com o caráter universal e não datado de suas produções e de seu estilo. A representação do comportamento humano, da sociedade burguesa, desloca-se para um retrato irônico dos mesmos. Da representação objetiva passa-se ao delineamento da subjetividade dos personagens, volatilizando, desse modo, o modo objetivo até então reinante.

Machado, com esta nova postura, atualiza os métodos e influencia seus predecessores. Do projeto realista europeu, o escritor explora a técnica da descrição considerada como o principal procedimento realista -, mas não pelo modo como foi tão criticada, em seu exagero e em sua falta de informação narrativa, mas, sim, na articulação que tal procedimento consegue engendrar na constituição do caráter das personagens e não mais seus contornos, ou seja, apenas adornos descritivos do ambiente em si. Há, por intermédio dessa nova postura, um retrato possível do indivíduo, enquanto ser dotado de singularidades, bem como a possibilidade, ainda, do delineamento, a partir do individual, da sociedade como um todo. Ainda que alguns críticos considerem uma ruptura plena de Machado com os conceitos necessários para a presença da mimese em suas obras, o que existe é, pela autorreflexividade inerente de seus métodos, um revigorar, inclusive, dos rumos necessários para a ficção progredir, sem prejuízo algum impresso neste termo.

Retomando, portanto, a tradição autoconsciente do ficcional, infere-se, num jogo intertextual evidente, que os romances Memórias póstumas de Brás Cubas e Dom Casmurro dialogam, explicitamente, com a obra The life and opinions of Tristram Shandy, gentleman $(1759,1767)$; considerado como um romance paradigma da forma autorreflexivaque expõe, na sua feitura, as características que definem e compõem a tradição autoconsciente. Tomando como base, portanto, os procedimentos trabalhados por Sterne, Alter afirma que

${ }^{11}$ BOSI, Alfredo. Machado de Assis: o enigma do olhar. São Paulo: Ática, 1999. 
Tristram Shandy, sob muitos aspectos o romance autoconsciente supremo e certamente o seu paradigma, fornece a mais vívida ilustração desse ponto essencial. Ele manifesta continuamente, no tocante à representação da realidade na ficção, uma atitude típica da formação em três camadas: em primeiro lugar, uma hiperconsciência da pura arbitrariedade e convencionalidade de todos os meios literários, desde a tipografia e divisão em capítulos às personagens e ao enredo; ao mesmo tempo uma demonstração paradoxal, talvez manifesta particularmente nas brilhantes improvisações estilísticas de Sterne, do poder ilusionista das representações ficcionais da realidade $\mathrm{e}$, finalmente, um constante envolvimento do leitor nas arbitrárias funções estruturadoras da mente, as quais, por sua vez, enquanto registro de nossa experiência mental mais íntima, tornam-se parte da realidade representada no romance. ${ }^{12}$

Nota-se, considerando os trechos em destaque, que, para se ler a autoconsciência em um romance, é necessário, segundo a proposta de Alter, a presença de tais características trabalhadas pelos procedimentos narrativos de uma trama e que podem definir, por sua vez, uma configuração estável e reflexiva de ficcionalidade. A exploração, desse modo, em um romance, da "hiperconsciência da pura arbitrariedade e convencionalidade de todos os meios literários", do "poder ilusionista das representações ficcionais da realidade" e de um "constante envolvimento do leitor" constituem as três "camadas" necessárias, para o autor, para uma possível identificação da reflexividade ficcional por meio desses índices intensificadores do escancaramento do processo de feitura e, inclusive, de exploração da própria concepção de mimese pela trama.

Com alguns pontos (possíveis) de contato com as três camadas postuladas por Alter, o crítico e filósofo alemão Wolfgang Iser, em seu texto "O fíctício e o imaginário", ${ }^{13}$ ao aprofundar a interação existente entre o conceito de fictício e o conceito de imaginário, a qual origina a literatura, afirma que o conceito de ficção, por ter em sua própria etimologia o ato de fingir (fingere), dá a ver a sua constituição por intermédio, também, de três modos discerníveis de fingimento, os quais estabelecem, por sua vez, os limites do jogo existente na interação ficcional de um texto literário. São eles: o ato de seleção, o ato de combinação e o ato de autodesnudamento.

\footnotetext{
${ }^{12}$ Idem, p. 138. Grifos meus.

${ }^{13}$ ISER, Wolfgang. O fictício e o imaginário. In: ROCHA, João Cezar de Castro (Org.). Teoria da ficção: indagações à obra de Wolfgang Iser. Rio de Janeiro: EdUERJ, 1999. p. 63-78.
} 
No ato de seleção, a ficção recorta elementos considerados extratextuais e intertextuais; no ato de combinação, há a organização e o tratamento, já enquanto forma, dos sintagmas selecionados, criando efeitos de sentido como, por exemplo, ilusão, cinismo, linearidade, embaralhamento etc., por intermédio de uma linguagem específica, também selecionada; por fim, no ato de desnudamento, temos a instalação de um "engano consentido", é o como se fosse real, representando uma espécie de contrato feito entre quem escreve e quem lê, de aceitar a feitura da trama sem desconfianças do real selecionado e do modo como foi combinado.

Com tal movimento, pela enunciação, a literatura faz o quer e o que pode. Se alguém pode inventar o que é fingido, acaba dando "veracidade" ao que é próprio da invenção. A realidade do texto, portanto, não é, nunca, uma verdade palpável, extratextual, mas, sim, uma invenção compartilhada e tramada pelas veredas do texto. Pelos mecanismos de engendramento de sentido, tais atos de fingimento convencem o leitor a adentrar nesse jogo de fidúcia do relato, como encontramos comumente nos romances de tradição autoconsciente, uma vez que estes extrapolam, seja por intermédio da teatralidade, do palco em cena, da feitura à mostra ou de cortinas aparecendo, o desnudar escancarado para que nada fique desleal para com o leitor que aceitou fingir para fruir do ficcional. Seleciona-se o que é de fora ou o que já é de dentro para combinar, com as potencialidades da linguagem, e evidenciar tal trabalho por intermédio das explorações dos graus de fingimento que perpetuam no leitor e fazem com que ele adentre no imaginário da literatura e do retrato possível, dentro das limitações linguísticas existentes, da sociedade em questão.

Nesse sentido, o romance Dom Casmurro ${ }^{14}$ pode ser interpretado dentro da referida filiação autoconsciente e que preconiza tal movimento do fingir, por apresentarse como um texto que se revela, em toda a sua feitura, como um artifício à mostra e em construção, que alerta, a todo o momento, seu leitor para o fato de estar presenciando uma narrativa que pretende afirmar-se como verídica, pautada pela elaboração de um

\footnotetext{
${ }^{14}$ ASSIS, Machado de. Dom Casmurro. Apresentação de Paulo Franchetti \& Notas e Comentários de Leila Guenther. Cotia, SP: Ateliê Editorial, 2008.
} 
real ficcional, mas contada por um "narrador hipocondríaco", aos moldes de Sterne, ou de crença "volúvel", como nos ensina Roberto Schwarz. ${ }^{15}$

Sendo a memória a matéria literária desse romance, podemos refletir sobre o modo como a questão da mimese, ao ser retratada como resquícios de um relembrar do vivido, pode ser questionada, ainda mais, no seu modo de ser representada, por ser material problematizante do próprio romance. Dom Casmurro, ao apresentar um narrador tocado pelos afetos que o compõem e, consequentemente, que distorce os fatos narrados, mostra-se como um romance que (des)vela não só sua construção composicional enquanto trama, mas (re)velador também dessa possibilidade de reflexão intensificadora sobre a representação da mimese. A presença da autoconsciência no romance pode, então, ser compreendida pelo modo como sua seleção, combinação e, consequentemente, completa destruição pelo escancaramento do processo ficcional foram trabalhadas e evidenciadas pelo escritor. Para Robert Stam, no capítulo "O romance autoconsciente de Henry Fielding a David Eggers", de seu livro A literatura através do cinema,

Aproximadamente um século após Tom Jones, Machado de Assis escreveu conscientemente dentro da tradição reflexiva de Cervantes, Sterne e Fielding. Como eles, seu estilo é muitas vezes autocorretivo; é uma escrita, como diria Derrida, "sob suspeita", ou em vias de apagamento. Machado constantemente anatomiza sua própria expressão num desmantelamento metalinguístico obsessivo de sua própria prática. Seu senso crítico está sempre em alerta, pronto para censurar seus próprios lapsos de anticlímax ou vulgaridade. O protagonista narrador de Dom Casmurro, por exemplo, num determinado momento alega que sua partida forçada para a Europa provocou mais lágrimas do que todas as que foram derramadas desde o tempo de Adão e Eva. Instantaneamente lamentando sua hipérbole, ele reconhece o exagero, mas insiste que "é bom ser enfático de vez em quando". Mesmo as metáforas normalmente funcionando como veículos transparentes de analogias, Machado muitas vezes as explica. Ao invés de servir-se delas como produtos prontos para consumo, ele as expõe em seu processo de elaboração, muitas vezes propondo metáforas somente para descartá-las por sua ineficiência: "Não, esta comparação não está boa". ${ }^{16}$

${ }^{15}$ SCHWARZ, Roberto. Um mestre na periferia do capitalismo: Machado de Assis. São Paulo: Duas Cidades; Ed.34, 1990.

${ }^{16}$ STAM, Robert. A literatura através do cinema: realismo, magia e a arte da adaptação. Belo Horizonte: Editora UFMG, 2008. p. 172. 
Temos, assim, uma reflexividade à mostra e posta em discussão com e para o leitor, o qual é convocado a participar, preencher e entender as lacunas do texto ou mesmo a trama enredada. Na literatura de Machado, a escrita "escreve-se e reescreve-se sob os olhos do leitor e supostamente com a ajuda dele", ${ }^{17}$ desenvolvendo uma relação lúdica com seus destinatários que encontram, a seus serviços, o processo de feitura colocado em evidência e, até mesmo, em questão..

Em Dom Casmurro, especificamente, temos, ao mesmo tempo, o relato do que se passa na memória de um narrador "volúvel", que relembra os fatos vividos, juntamente com o relato da construção do mesmo, ao interromper, deslocar e desviar a atenção do leitor, produzindo um efeito de sentido de nebulosidade do narrado. A autoconsciência ficcional do relato atinge seu ápice, uma vez que a própria verossimilhança da estória narrada perpassada a memória desse narrador ensandecido, desconfiável e absolutamente ambíguo. Nada se sabe ao certo, nada se conclui de fato.Há, apenas, sugestões, impressões, delineamentos de acontecimentos rememorados por uma mente assombrada pelos fantasmas do que poderia ter sido e não foi.

O que resta é adentrar no jogo proposto pela ficção e fingir aceitar tais fatos contados para que tenhamos um fluir narrativo. O movimento, portanto, do que foi selecionado por esse narrador, combinado por sua memória e desnudado por um contar reflexivo caracteriza o romance como um expoente notório de uma tradição autoconsciente de sua própria ficcionalidade. João Adolfo Hansen, em artigo intitulado "Dom Casmurro: simulacro \& alegoria", ao discutir a representação na obra, afirma que

Provisória, artificiosa e precária, como pretensão de conhecimento de si mesma e do passado, a ficção escrita por Dom Casmurro é prática em que a própria noção contemporânea de "literatura" aparece indeterminada. Não é mais a janela transparente de românticos, realistas e naturalistas, em que a própria mediação da narrativa, a representação, aparece como forma interposta de vidro transparente que, refletindo tudo da paisagem exterior como totalidade prévia do social, não se vê a si mesma como forma simbólica também social, produzida numa prática que destrói os espelhos. Como categoria teórica, analítica, técnica e descritiva organizada por meio da noção de "semelhança" em várias modalidades - unidade do real, totalidade,

${ }^{17}$ Ibidem. 
consciência, memória, contínuo evolutivo, verismo, imitação, adequação de significante e significado, verossimilhança, totalização a representação aparece abalada em Dom Casmurro. ${ }^{18}$

Instaurada, portanto, a crise de representação nesse romance, e conciliada com a manifestação explícita da autoconsciência ficcional reconhecida pela tradição, interessa pensar, aqui, como tais reflexões manifestam-se - pensando nas "três camadas" caracterizadoras do romance autoconsciente, bem como no movimento de seleçãocombinação e autodesnudamento (pensado por Iser) - em um processo de transposição de um texto verbal, o romance machadiano, para um texto sincrético; no caso, uma minissérie televisiva.

Pretende-se, também, verificar a possibilidade da seguinte reflexão: se o gênero romance pode ser considerado como um espaço mais propenso para manifestação do verossímil do que do inverossímil, seria, então, o gênero minissérie - levando em consideração sua materialidade - o gênero mais apto para se desenvolver um espaço para uma representação mais eficaz do inverossímil? Justamente pela infinidade de recursos artificiais que podem ser mobilizados para uma construção artificial desse poder de ilusão tão característico da mimese após sua crise? A resposta parece estar nas produções artísticas e contemporâneas do diretor Luiz Fernando Carvalho, nas quais encontramos a ficção como matéria principal de discussão.

\section{Atando as pontas do romance com as pontas da minissérie}

O enunciador da minissérie Capitu, ${ }^{19}$ antes de ser um realizador da transposição de uma obra literária para outro gênero, o televisivo, torna-se leitor ativo e crítico das relações intertextuais e extratextuais com as quais Machado soube ancorar em seu texto. Alçando, desse modo, um movimento próprio de interpretação, consegue explorar e combinar, sobre o ponto de vista que será lançado e mediado pelas escolhas

18 HANSEN, João Adolfo. Dom Casmurro: simulacro \& alegoria. In: SECCHIN, Antonio Carlos; BASTOS, Dau; JOBIM, José Luís (Orgs.). Machado de Assis: novas perspectivas sobre a obra e o autor no centenário de sua morte. Niterói; Rio de Janeiro: Eduff; De Letras, 2008. p. 160.

${ }^{19}$ CAPITU. A partir do romance Dom Casmurro de Machado de Assis. Escrito por Euclydes Marinho. Colaboração Daniel Piza, Edna Palatnik, Luís Alberto de Abreu. Texto final e direção geral de Luiz Fernando Carvalho. Distrito Industrial Manaus: Sistema Globo de Gravações Audiovisuais LTDA, 2009. 2 DVD'S, widescreen, color. Produzido por Globo Marcas DVD e Som Livre. 
significativas, que sua leitura seja projetada na realização, mostrando um caminho profícuo e eficaz para uma análise que quer conjugar as relações recíprocas, e, por que não, dialógicas, existentes entre literatura e cinema, literatura e televisão.

A representação do inverossímil - dada pelos recursos mobilizados em uma produção visual - favorece o gênero minissérie ao conseguir, com mais facilidade, representar e apresentar, de modo escancarado e autoconsciente, os mecanismos de feitura mobilizados para dar um tom de ficcionalidade à realização. Contudo, ao mostrar-se, por intermédio dos efeitos de sentidos obtidos por tais recursos sincréticos, como detentor de um poder ilusionista um tanto quanto maior, o gênero minissérie acaba, concomitantemente a esta constatação, por reforçar a instaurada discussão sobre a crise da mimese, pois, ao destruí-la com seu escancaramento do uso de recursos artificiais, acaba retomando e colocando em cena, a todo o momento, sua existência no jogo lúdico de uma realização.

Vale ressaltar, contudo, que tais reflexões podem ser levadas em consideração em relação às minisséries realizadas pelo diretor Luiz Fernando Carvalho - e dentro do contexto delas -, que apresenta, como um dos fundamentos de sua "poética"composicional, ${ }^{20}$ justamente a proposta de levar para o formato televisivo e, em consequência, para o conhecimento dos seus telespectadores, essas discussões sobre o exercício de reflexão sobre o fazer em si, envolto num processo de transposição de uma obra literária para outro suporte.

O que o enunciador sincrético faz em sua realização é expor, de modo mais explícito, o que já estava representado na obra machadiana Dom Casmurro, em relação à manifestação de uma reflexividade à mostra. O que o diferencia, no entanto, dos demais realizadores de minisséries, é a recorrência com que tal denúncia dos seus procedimentos é feita, conseguindo produzir, assim, outros sentidos para obra não só pelo fato de explorar os procedimentos metalinguísticos ao longo da trama, como é característico dessa tradição, mas, principalmente, pelo escancaramento dos recursos

\footnotetext{
${ }^{20} \mathrm{O}$ estudo da poética do diretor Luiz Fernando Carvalho encontra-se em andamento, com nosso projeto de pesquisa, em nível de mestrado, intitulado "Entre o riso e a melancolia: a confluência de leituras na transposição do romance Dom Casmurro para a minissérie Capitu", sob a orientação da Profa. Dra. Maria de Lourdes Ortiz Gandini Baldan.
} 
que fazem a minissérie ser construída por uma ficcionalidade altamente reflexiva, que mimetiza, inclusive, o próprio conceito de mimese.

Deste modo, infere-se que ambas as realizações podem ser interpretadas sob o viés de uma tradição de romances autoconscientes de seus fazeres e que expõem para os leitores a tarefa realizada em uma composição artística, seja ela verbal, seja sincrética. A crise da representação acentuada por Machado, ao ser aliada ao escancaramento da artificialidade de Carvalho, parece ter fornecido matéria diversa, e fundamental, para a recriação necessária de uma possível realidade a ser representada na televisão para um público que necessita de um tipo de ancoramento "sólido" dos fatos. Ao produzir suas realizações dentro daquela que é considerada a maior emissora de televisão do país, a Rede Globo de Televisão, Carvalho parece atender a demanda contemporânea de retomada do real, colocando em discussão a feitura dos seus procedimentos, bem como convidando o telespectador a entender o movimento que a ficção delineia ao trabalhar com fatos externos ou internos a ela.

Pode-se afirmar, portanto, que há, no projeto estético de Carvalho, o seguinte movimento: o selecionar do material que será trabalhado e/ou transposto, sua respectiva combinação numa linguagem específica e/ou em outro suporte, e, por fim, como os artifícios anteriores utilizados são desnudados, ou seja, o modo como o andaime da construção é (auto)mostrado.
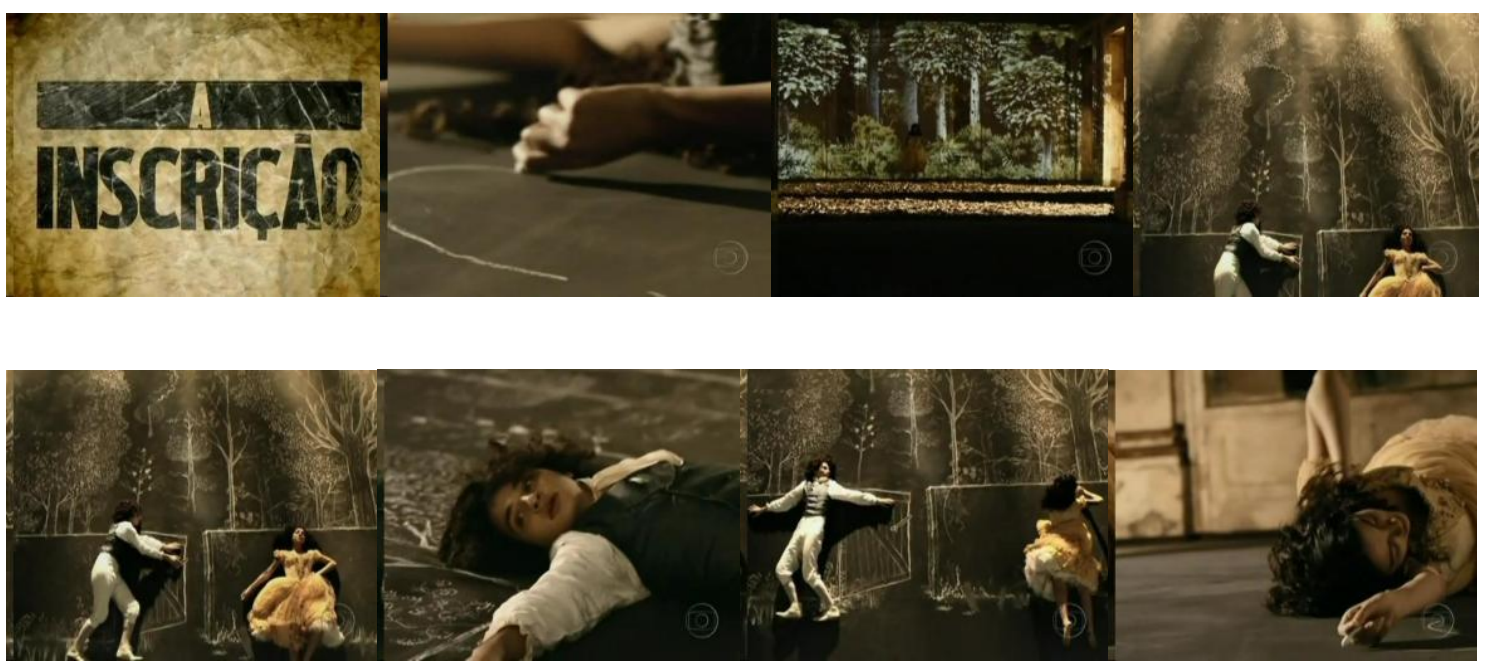

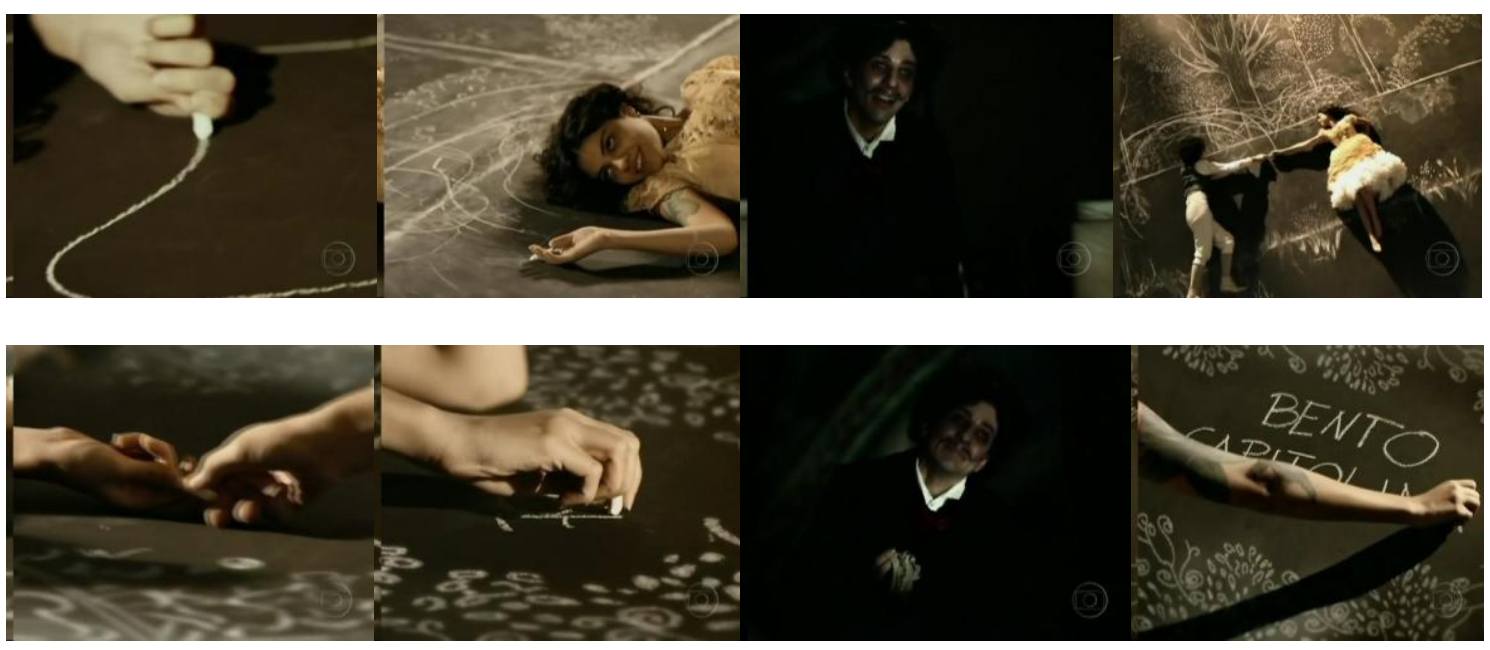

Plano-sequência correspondente ao capítulo XIV, "A inscrição".

Luiz Fernando Carvalho parece expandir o limite da representação e rever, inclusive, os limites do real, ainda que esta relação se mostre de modo ínfimo em algumas realizações. O que fica claro, no entanto, é que por mais que se possa expandir a presença do real pelo gênero minissérie, ao explorar os recursos tecnológicos de produção e inserção de elementos artificiais à mostra, há, sempre, limites a serem estabelecidos, como podemos observar na sequência reproduzida acima. Infere-se, assim, que a construção desses cenários que se assemelham a verdadeiros quadros pintados, traçados ou panos esboçados, mesclados, em sua constituição, com "elementos reais" da natureza, como as folhas esparramadas no chão, corroboram, também, para a manutenção e intensificação das camadas denunciadoras do processo de autoconscientização ficcional presente.

Em Capitu, há, notoriamente, uma mediação com o livro e uma mediação com o real. Como numa tríade, temos o retrato do Rio de Janeiro do século XIX, o romance ambientado nesse Rio de Janeiro de 1857 e, por fim, a minissérie que transpõe esses dados para um cenário atemporal, marcado por uma leitura contemporânea dos fatos. A mediação entre essas esferas de circulação e produção apresentam-se na realização final de Carvalho por este optar pela mescla, por exemplo, de figurinos tidos como de época com uma musicalidade altamente moderna e até mesmo de cultura pop.

O que existe de manutenção de dados reais é a representação dos costumes impingidos pela sociedade a um indivíduo preso às tradições burguesas, as quais representadas, por sua vez, nas descrições que imprimem caráter a cada personagem da 
trama e que determinam, diretamente, o do protagonista Bentinho. A castração por parte de sua mãe, a ambição e o interesse de José Dias, o comodismo de Primo Cosme e a sátira de Prima Justina são apenas alguns índices que irão compor a personalidade altamente influenciável do advogado Bento Santiago. Na minissérie, há a transposição de tais índices, de modo extrapolado, pela gestualidade das personagens e pelo trato bufo, grandiloquente e caricaturesco dado pelos atores que os encenam.

Há, ainda, a atualização e o deslocamento dos valores políticos e históricos predominantes na passagem do século XIX para o século XX; contudo a maneira como tal postura realista de retrato é combinada apresenta-nos um novo método para apreender o aspecto do real inserido na minissérie. Carvalho opta por esgarçar um real fabricado, selecionando, do romance, as passagens que mais se aproximam do que podem ser considerados fatos concretos, plausíveis e verificáveis na história, para combiná-los, na minissérie, por intermédio do recurso a planos-sequências montados a partir de fotografias em preto e branco, deixando claro, assim, de modo lúdico e escancarado, o que é história e o que é estória.
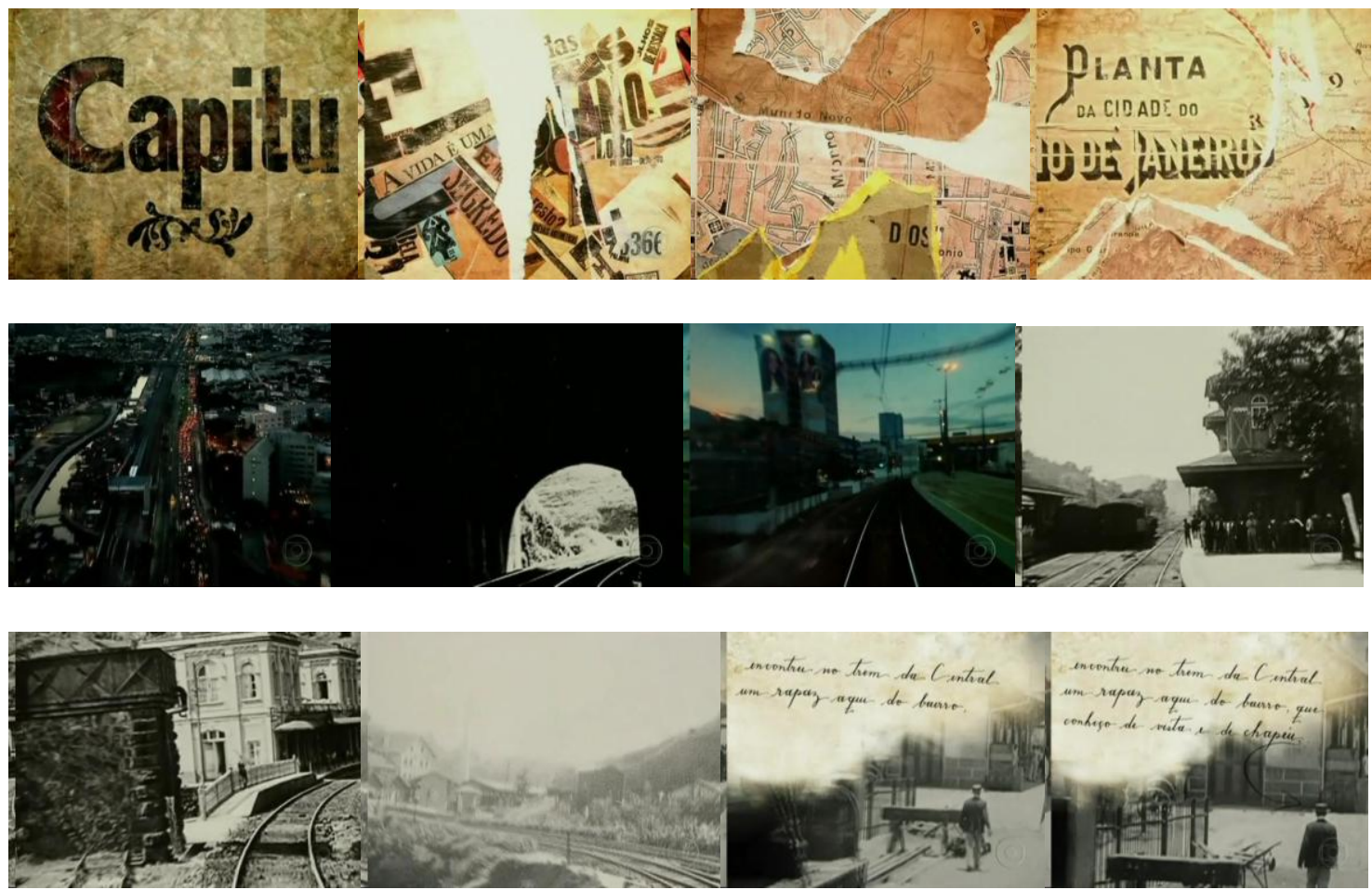

Plano-sequência de abertura da minissérie Capitu. 
Assim, a dimensão do real, na minissérie, é trabalhada de modo estrutural, pelos efeitos construídos em tais inserções constantes de quadros representativos da época. Cria-se a ilusão pretendida e o fingimento consentido de algo que poderia ter acontecido ou aconteceu nessa realidade atestada pelas imagens, quando, de fato, encontramos mais uma interação lúdica e manipuladora do enunciador que reflete e demonstra, conscientemente, como o real engendra-se como matéria para a ficção.

O movimento, inclusive, de incorporação do real é de dentro para fora do texto, e não de fora para dentro. Verifica-se a presença de uma dimensão ética da narrativa e a incorporação de uma reflexividade sobre a representação, por meio do recurso midiático, na construção de uma trama televisiva que transita entre realidade e ficção, entre o acontecido e o que poderia ter acontecido no romance. Presenciamos o diálogo não só com os discursos retomados da crítica tradicional, com os da crítica moderna, mas das polêmicas discussões que vigoraram entre os críticos sobre o realismo presente nas obras de Machado de Assis, expressas pelo movimento de incorporação da dimensão do real na expressão da minissérie.

O diretor, desse modo, retoma a premissa realista do romance, na realização televisiva, ou trazendo imagens do que, de fato, aconteceu, ou fingindo, artificialmente, pelos recursos, que aquilo corresponde ao fato concreto. Afirmando, inclusive, partir da própria premissa de Machado, quando este afirmou, certa vez, que "a realidade é boa, o realismo é que não presta para nada" ${ }^{21}$, Luiz Fernando Carvalho parece criticar a leitura castradora e classificatória do romance dentro do viés realista, uma vez que a transposição enaltece a possibilidade de atemporalidade da obra. Podemos apreender esta leitura dotada por uma credulidade crítica quando Carvalho opta, exatamente nos momentos mais descritivistas da trama, por inserir as tais sequências de fotografias em preto e branco, alçadas por essa tentativa de trazer a dimensão do real ao relato.

Esse tratamento imagético dado à descrição, enquanto reconhecida técnica preferencial do realismo, parece jogar, ironicamente, com as críticas feitas pelo estudioso Roland Barthes, em seu clássico texto "O efeito de real", ${ }^{22}$ sobre a

\footnotetext{
${ }^{21}$ ASSIS, Machado de. A nova geração In: Crítica literária. Rio de Janeiro: W M Jackson Inc Editores, 1946.

${ }^{22}$ BARTHES, Roland. O efeito de real. In: O rumor da língua. Lisboa: Edições 70, 1987. p. 131136.
} 
insignificância de uma possível significação para o recurso da descrição nas narrativas. Para o estudioso, a descrição não contém nenhuma informação narrativa, não faz ação nenhuma girar, simplesmente imprime uma suspensão no tempo da história e uma continuação no tempo do discurso. Atuando como um "efeito retardador", a descrição aponta para uma digressão narrativa, como algo acessório que, se tirado do discurso, nada altera ou prejudica a trama em si.

Mostrando-se um leitor crítico, Luiz Fernando Carvalho parece criar um método em sua transposição para criticar e retomar essa reverberação que a função da descrição representou no ápice das discussões sobre o realismo e suas caracterizações. Tal método parece se dar, como já referido anteriormente, na inserção do real por intermédio de imagens em preto em branco de um Rio de Janeiro do século XIX. Com tal estratégia, o diretor não só alia mais uma leitura crítica sobre a obra machadiana, uma vez que o rótulo realista sobre a obra Dom Casmurro engessou diversas leituras, como também explora, de modo irônico e reflexivo, como o do escritor, o efeito de sentido criado de uma espécie de borramento existente entre o dado que aponta para o real e o dado que aponta para a ficção.

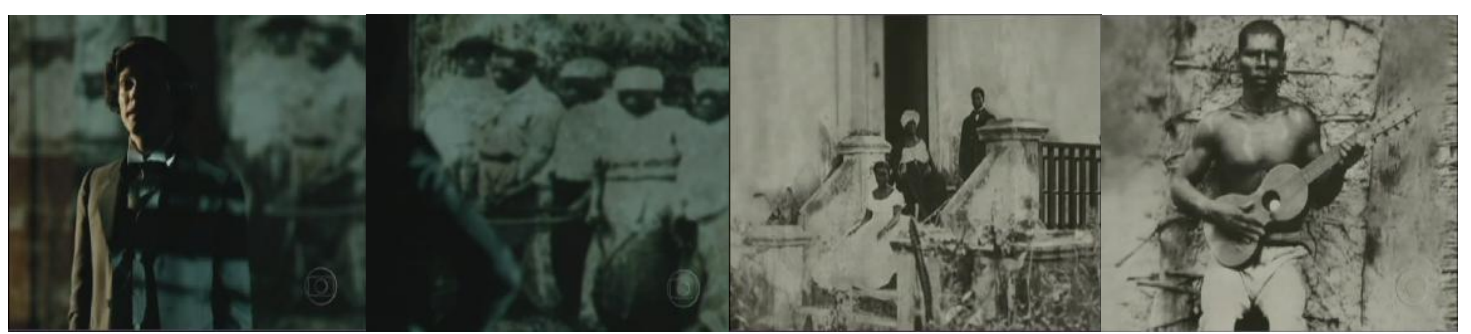

Plano-sequência correspondente ao capítulo LXXI, "Visita de Escobar".

Há o registro de um real palpável, ainda que filmado, por mobilizar tais tentativas de representação; contudo, o diretor acrescenta, ainda, a esse seu modo de composição reflexivo, um método de bricolagem que, ${ }^{23}$ num primeiro momento, não se mostra de fácil apreensão, por ter sua inserção no decorrer da história de modo, aparentemente, sem nexo direto. Contudo, como mostra o recorte da sequência acima, a presença de quadros correspondentes às cenas de escravos do Rio de Janeiro, no

\footnotetext{
${ }^{23}$ Vale ressaltar, inclusive, que Luiz Fernando Carvalho explora a técnica de bricolagem, nas suas demais realizações, com objetos e combinações não do uso massificador, mas para o uso massificador, possibilitando, assim, uma participação ativa do telespectador que apreende, ludicamente, o processo da feitura e da leitura da transposição em questão.
} 
momento em que Escobar visita, pela primeira vez a casa da família de Bento Santiago, engendra uma sutileza de interpretação que é perceptível se pensada dentro do movimento sutil de crítica que Machado faz, ao longo do romance, sobre a exploração da escravidão naquele contexto. Tachado, por muitos, de alienado aos problemas sociais vigentes na sociedade, a universalidade de sua obra fez com que muitas leituras errôneas perseverassem ,quando, na verdade, um trato fino e sutil das mazelas denuncia, quase sempre, muito mais do que uma explicitação dos fatos.

Ainda que limites sejam estabelecidos pela própria pausa no andamento da minissérie quando tais quadros são inseridos, infere-se que a encenação construída pelo diretor não constitui somente uma mera tentativa de chamar a atenção para dissonância que o real de tais quadros representa na narrativa, mas, sim, para uma representação pensada em profundidade crítica. . O real, assim, retorna, na aproximação contemporânea da obra machadiana, como algo a ser pensado criticamente e reflexivamente. Como categoria formal necessária para consolidar o jogo lúdico entre o autor e seu leitor, entre o diretor e seu telespectador, a dimensão do real é compreendida como efeito de sentido necessário para o engendramento e entendimento do conceito de ficção na realização em questão.
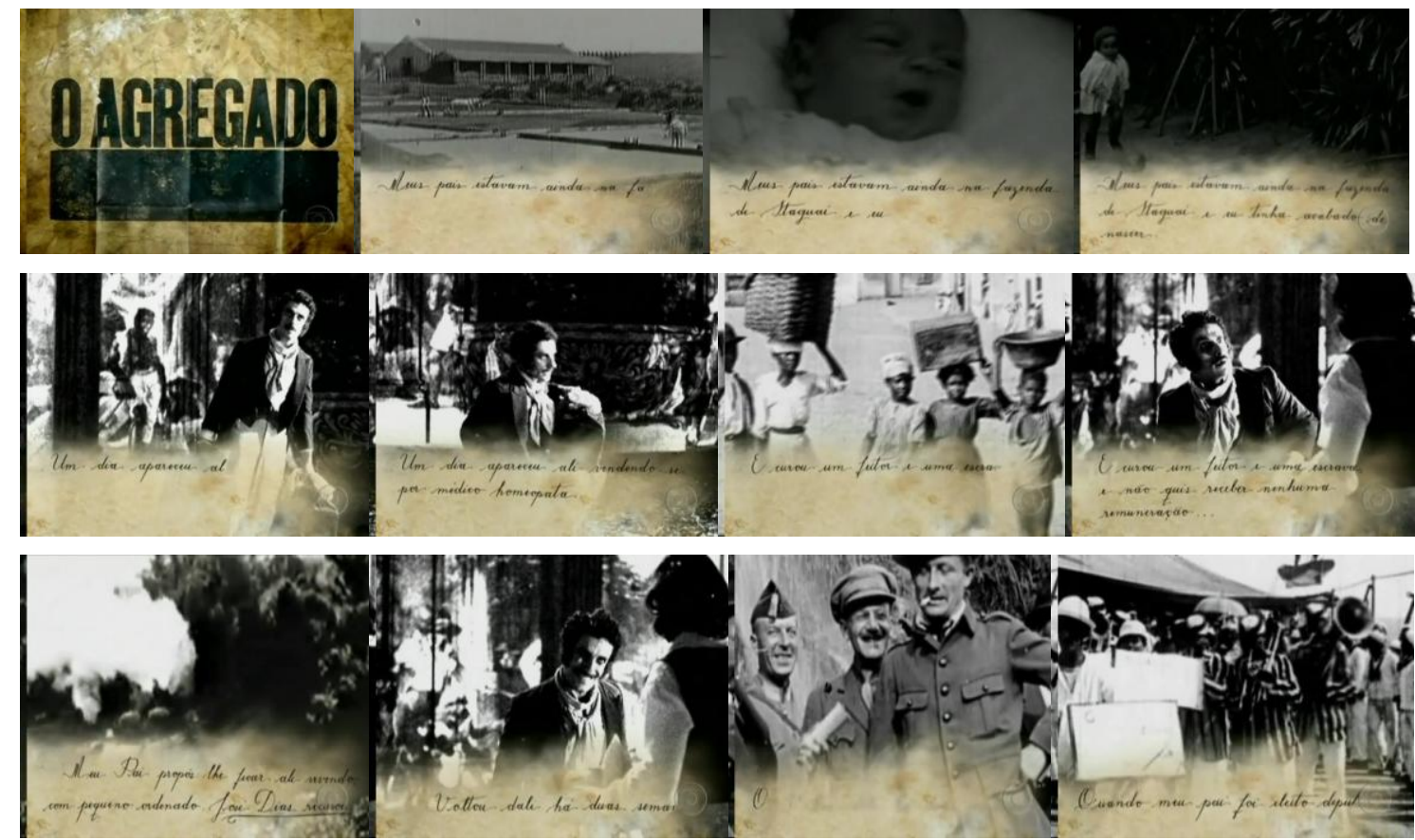


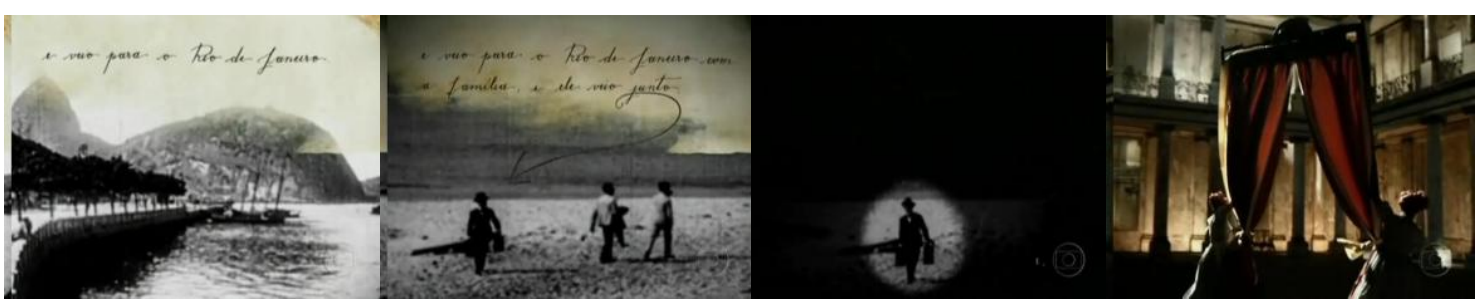

Plano-sequência correspondente ao capítulo V, "O Agregado".

A exploração do fingimento na minissérie, máscara necessária para se prestar um serviço à cultura de massa, permite o esgarçamento do próprio domínio da ficcionalidade. É como se a ficção se autoesgarçasse para revelar o próprio fingimento que a constitui. O desdobramento do ato de fingir, pela interação entre os atos de seleção, de combinação e de autodesnudamento, confere o complemento necessário às três referidas camadas da tradição autoconsciente, uma vez que o acesso à "hiperconsciência da pura arbitrariedade e convencionalidade de todos os meios literários", ao "poder ilusionista das representações ficcionais da realidade" e ao "constante envolvimento do leitor" representa os requisitos mínimos para a consolidação da encenação que define, inclusive, a própria literatura.

Carvalho, desse modo, procurou mimetizar, em sua ficção, a ficção trabalhada por Machado. Ele encena, na televisão, o que a literatura encena no espaço que lhe concerne, construindo, em Capitu, a possibilidade de um estudo da presença da mimese na ficção. O crítico e poeta Haroldo de Campos $^{24}$ notou que o nome da personagem "Capitolina" remete a "capítulo"; Carvalho, por sua vez, ao atribuir o título Capitu, em sua encenação visual, dá a ver o capítu(lo) à parte, na própria literatura, que veio a ser o romance machadiano em questão, com sua consciente ambiguidade ficcional.

Fingindo, por intermédio de efeitos de cinismo, teatralidade ou performatividade, Luiz Fernando Carvalho criativamente e criticamente consolida o espaço da mimese, agora numa incorporação pela ficção televisiva, apontando, inclusive, nesse movimento, para as diversas vozes que atravessam a obra e a literatura. Movidos cada um com as suas convicções e com as contextualizações do tempo que os circundam, Machado de Assis e Luiz Fernando Carvalho parecem dialogar entre si, com suas respectivas obras, no tempo presente, ao mostrarem-se como continuadores de uma

\footnotetext{
${ }^{24}$ SCHPREJER, Alberto. Vamos à história dos subúrbios. In: SCHPREJER, Alberto. (Org.) Quem é Capitu?. Rio de Janeiro: Nova Fronteira, 2008. p. 9-10.
} 
tradição de autoconsciência ficcional, cada um ao seu modo, cada com seu gênero, cada um com seus atos de fingimentos de graus variados; contudo, cada um dentro do outro, atualizando e retomando, um ao outro, , como diria Bentinho, "como a fruta dentro da casca".

Referências:

ALTER, Robert. A mimese e o motivo para a ficção. In: Em espelho crítico. São Paulo: Perspectiva, 1998.

Partial magic: the novel as a self-conscious genre. Berkeley, CA: University of California Press, 1975.

ASSIS, Machado de. A nova geração In: Crítica literária. Rio de Janeiro: W M Jackson Inc Editores, 1946.

Dom Casmurro. Apresentação de Paulo Franchetti \& Notas e Comentários de Leila Guenther. Cotia, SP: Ateliê Editorial, 2008.

BARTHES, Roland. O efeito de real. In: O rumor da língua. Lisboa: Edições 70, 1987. p. 131-136.

BOSI, Alfredo. Machado de Assis: o enigma do olhar. São Paulo: Ática, 1999.

CAPITU. A partir do romance Dom Casmurro de Machado de Assis. Escrito por Euclydes Marinho. Colaboração Daniel Piza, Edna Palatnik, Luís Alberto de Abreu. Texto final e direção geral de Luiz Fernando Carvalho. Distrito Industrial Manaus: Sistema Globo de Gravações Audiovisuais LTDA, 2009. 2 DVD'S, widescreen, color. Produzido por Globo Marcas DVD e Som Livre.

FIORIN, José Luiz. Introdução ao pensamento de Bakhtin. São Paulo: Ática, 2006.

HANSEN, João Adolfo. Dom Casmurro: simulacro \& alegoria. In: SECCHIN, Antonio Carlos; BASTOS, Dau; JOBIM, José Luís (Orgs.). Machado de Assis: novas perspectivas sobre a obra e o autor no centenário de sua morte. Niterói; Rio de Janeiro: Eduff; De Letras, 2008.

ISER, Wolfgang. O fictício e o imaginário. In: ROCHA, João Cezar de Castro (Org.). Teoria da ficção: indagações à obra de Wolfgang Iser. Rio de Janeiro: EdUERJ, 1999. 
PELLEGRINI, T. Realismo: postura e método. Letras de hoje. Porto Alegre, v.42, n.4, p.137-155, dez./2007.

REGO, Enylton de Sá. O calundu e a panaceia: Machado de Assis, a sátira menipeia e a tradição luciânica. Rio de Janeiro: Forense Universitária, 1989.

ROUANET, Sergio Paulo. Riso e melancolia: a forma shandiana em Sterne, Diderot, Xavier de Maistre, Almeida Garret e Machado de Assis. São Paulo: Companhia das Letras, 2007.

SCHPREJER, Alberto. Vamos à história dos subúrbios. In: SCHPREJER, Alberto. (Org.) Quem é Capitu?. Rio de Janeiro: Nova Fronteira, 2008.

Cristiane Passafaro Guzzi é licenciada e bacharel em Letras pela Universidade Estadual Paulista. Atualmente, é aluna de mestrado do Programa de Pós-Graduação em Estudos Literários da UNESP/FCLAR. Tem especialização em "Teorias Linguísticas e Ensino", curso oferecido pelo Programa de Pós-Graduação em Linguística e Língua Portuguesa da mesma instituição. Foi bolsista e pesquisadora de Iniciação Científica pela FAPESP, por dois anos consecutivos. É pesquisadora do Grupo de Pesquisa CASA - Cadernos de Semiótica Aplicada, atuando como secretária técnica da Revista Eletrônica do Grupo. Participa, ainda, do SLOVO - Grupo de estudos do discurso. E-mail: <crispguzzi@gmail.com>

Recebido: $19 / 02 / 2012$

Aprovado: 18/05/2012 